\title{
A PRELIMINARY ASSESSMENT OF THE OCCURRENCE AND POSSIBLE SOURCES OF MTBE IN GROUND WATER OF THE UNITED STATES, 1993-94
}

By Paul J. Squillace, John S. Zogorski, William G. Wilber, and Curtis V. Price

U.S. GEOLOGICAL SURVEY

Open-File Report 95-456

Rapid City, South Dakota

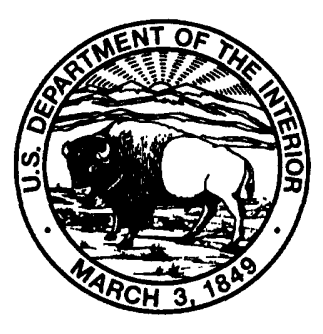




\section{U.S. DEPARTMENT OF THE INTERIOR \\ BRUCE BABBITT, Secretary \\ U.S. GEOLOGICAL SURVEY \\ Gordon P. Eaton, Director}

For additional information write to:

District Chief

U.S. Geological Survey

1608 Mt. View Rd.

Rapid City, SD 57702
Copies of this report can be purchased from:

U.S. Geological Survey

Earth Science Information Center

Open-File Reports Section

Box 25286, MS 517

Denver Federal Center

Denver, CO 80225-0425 


\section{FOREWORD}

The mission of the U.S. Geological Survey (USGS) is to assess the quantity and quality of the earth resources of the Nation and to provide information that will assist resource managers and policymakers at Federal, State, and local levels in making sound decisions. Assessment of water-quality conditions and trends is an important part of this overall mission.

One of the greatest challenges faced by waterresources scientists is acquiring reliable information that will guide the use and protection of the Nation's water resources. That challenge is being addressed by Federal, State, interstate, and local water-resource agencies and by many academic institutions. These organizations are collecting water-quality data for a host of purposes that include: compliance with permits and water-supply standards; development of remediation plans for a specific contamination problem; operational decisions on industrial, wastewater, or water-supply facilities; and research on factors that affect water quality. An additional need for waterquality information is to provide a basis on which regional and national-level policy decisions can be based. Wise decisions must be based on sound information. As a society we need to know whether certain types of water-quality problems are isolated or ubiquitous, whether there are significant differences in conditions among regions, whether the conditions are changing over time, and why these conditions change from place to place and over time. The information can be used to help determine the efficacy of existing water-quality policies and to help analysts determine the need for and likely consequences of new policies.

To address these needs, the Congress appropriated funds in 1986 for the USGS to begin a pilot program in seven project areas to develop and refine the National Water-Quality Assessment (NAWQA) Program. In 1991, the USGS began full implementation of the program. The NAWQA Program builds upon an existing base of water-quality studies of the USGS, as well as those of other Federal, State, and local agencies. The objectives of the NAWQA Program are to:

- Describe current water-quality conditions for a large part of the Nation's freshwater streams, rivers, and aquifers.
- Describe how water quality is changing over time.

- Improve understanding of the primary natural and human factors that affect water-quality conditions.

This information will help support the development and evaluation of management, regulatory, and monitoring decisions by other Federal, State, and local agencies to protect, use, and enhance water resources.

The goals of the NAWQA Program are being achieved through ongoing and proposed investigations of 60 of the Nation's most important river basins and aquifer systems, which are referred to as study units. These study units are distributed throughout the Nation and cover a diversity of hydrogeologic settings. More than two-thirds of the Nation's freshwater use occurs within the 60 study units and more than two-thirds of the people served by public watersupply systems live within their boundaries.

National synthesis of data analysis, based on aggregation of comparable information obtained from the study units, is a major component of the program. This effort focuses on selected water-quality topics using nationally consistent information. Comparative studies will explain differences and similarities in observed water-quality conditions among study areas and will identify changes and trends and their causes. The first topics addressed by the national synthesis are pesticides, nutrients, volatile organic compounds, and aquatic biology. Discussions on these and other waterquality topics will be published in periodic summaries of the quality of the Nation's ground and surface water as the information becomes available.

This report is an element of the comprehensive body of information developed as part of the NAWQA Program. The program depends heavily on the advice, cooperation, and information from many Federal, State, interstate, Tribal, and local agencies and the public. The assistance and suggestions of all are greatly appreciated.

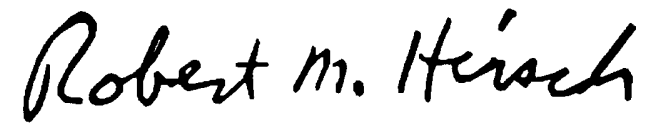

Robert M. Hirsch Chief Hydrologist 


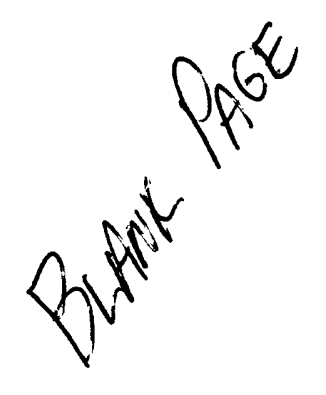




\section{CONTENTS}

Abstract

\section{ILLUSTRATIONS}

Figure 1. Map showing location of areas using oxygenated or reformulated gasoline, U. S. Geological Survey National Water-Quality Assessment (NAWQA) Study Units, and Urban and Agricultural Land-Use Studies

2. Graph showing concentrations of MTBE versus total concentrations of BTEX compounds in shallow ground-water samples from Urban Land-Use Study areas, 1993-94

3. Graph showing frequency of detection of MTBE in shallow ground water from Urban Land-Use Study areas, 1993-94

4. Graph showing concentrations of MTBE in shallow ground water from Urban Land-Use Study areas, 1993-94

5. Graph showing concentrations of MTBE in atmosphere and precipitation at various temperatures

TABLE

Table 1. Components and attributes of the National Water-Quality Assessment ground-water sampling design 
<smiles>[12BH][13CH2]</smiles> 


\title{
A PRELIMINARY ASSESSMENT OF THE OCCURRENCE AND POSSIBLE SOURCES OF MTBE IN GROUND WATER OF THE UNITED STATES, 1993-94
}

\author{
By Paul J. Squillace, John S. Zogorski, William G. Wilber, and Curtis V. Price
}

\section{ABSTRACT}

The 1990 Clean Air Act Amendments require fuel oxygenates to be added to gasoline used in some metropolitan areas to reduce atmospheric concentrations of carbon monoxide or ozone. Methyl tert-butyl ether (MTBE), is the most commonly used fuel oxygenate and is a relatively new gasoline additive. Nevertheless, out of 60 volatile organic chemicals analyzed, MTBE was the second most frequently detected chemical in samples of shallow ambient ground water from urban areas that were collected during 1993-94 as part of the U.S. Geological Survey's National Water-Quality Assessment program. Samples were collected from 5 drinkingwater wells, 12 springs, and 193 monitoring wells in urban areas. No MTBE was detected in drinkingwater wells. At a reporting level of $0.2 \mu \mathrm{g} / \mathrm{L}$ (micrograms per liter), MTBE was detected most frequently in shallow ground water from urban areas ( 27 percent of 210 wells and springs sampled in 8 areas) as compared to shallow ground water from agricultural areas ( 1.3 percent of 549 wells sampled in 21 areas) or deeper ground water from major aquifers ( 1 percent of 412 wells sampled in 9 areas). Only 3 percent of the shallow wells sampled in urban areas had concentrations of MTBE that exceed $20 \mu \mathrm{g} / \mathrm{L}$, which is the estimated lower limit of the U.S. Environmental Protection Agency draft drinking-water health advisory. Because MTBE is persistent and mobile in ground water, it can move from shallow to deeper aquifers with time. In shallow urban ground water, MTBE generally was not found with benzene, toluene, ethylbenzene, or xylenes (BTEX) compounds which commonly are associated with gasoline spills. This disassociation causes uncertainty as to the source of
MTBE. Possible sources of MTBE in ground water include point sources, such as leaking storage tanks, and nonpoint sources, such as recharge of precipitation and storm-water runoff.

\section{INTRODUCTION}

The 1990 Clean Air Act Amendments require fuel oxygenates, such as methyl tert-butyl ether (MTBE) or ethanol, to be added to gasoline used in some metropolitan areas to reduce atmospheric concentrations of carbon monoxide $(\mathrm{CO})$ or ozone $\left(\mathrm{O}_{3}\right)$. Areas that exceed the national ambient air-quality standard for carbon monoxide were required to use oxygenated fuels by November 1, 1992; however, fuel oxygenates have been used in some metropolitan areas since 1988 (Begley and Rotman, 1993) to improve air quality. The Clean Air Act Amendments also require oxygenated fuels during the winter when the concentrations of carbon monoxide are largest. Gasoline must contain no less than 2.7 percent oxygen by weight, which is equal to 15 percent MTBE by volume, to meet this oxygen requirement. Nine metropolitan areas that have the most severe ozone pollution were required to use a special blend of gasoline called reformulated gasoline year round beginning in January 1995. Numerous additional areas have chosen to participate in the reformulated gasoline program. Reformulated gasoline must contain at least 2.0 percent oxygen by weight, a maximum of 1.0 percent benzene and 25 percent aromatic hydrocarbon by volume. Reformulated gasoline would contain 11 percent MTBE by volume to meet this oxygen requirement. MTBE is a major volatile organic chemical (VOC) component in oxygenated and reformulated gasoline. 
About 109 million people live in counties where fuel oxygenates are used to meet either one or both of the requirements of the Clean Air Act Amendments of 1990 (fig. 1). MTBE also is used in many other undefined areas to enhance the octane of gasoline, but its use is not mandated in these areas. Currently, fuel oxygenates are added to more than 30 percent of the gasoline in the United States (U.S. Environmental Protection Agency, 1994) and by the year 2000 it is projected that fuel oxygenates will be added to 70 percent of the gasoline pool in the United States (Shelly and Fouhy, 1994).

At the request of U.S. Environmental Protection Agency (USEPA), the Office of Science and Technology Policy, Executive Office of the President, has initiated an interagency assessment of the scientific basis and efficacy of the reformulated fuel and oxygenated gasoline programs. This assessment is being conducted under coordination of the National Science and Technology Council's Committee on Environment and Natural Resources. The assessment will compare oxygenated fuels with conventional gasoline, where feasible, in the following areas: potential health impacts, fuel economy and engine performance, potential effects on ground-water and surface-water quality, air-quality benefits, and economic analysis. In the spring of 1996, a final draft report is scheduled to be submitted to the National Research Council for review and recommendations.

MTBE is the most commonly used fuel oxygenate because of its low cost, ease of production, and favorable transfer and blending characteristics (Ainsworth, 1992; Mormile and others, 1994; Shelly and Fouhy, 1994). It can be produced at the refinery, blends easily without phase separation in gasoline, and the gasoline blend can be transferred through existing pipelines. Feedstocks for MTBE include isobutylene and methanol. In 1994, 6.2 billion $\mathrm{kg}$ (kilograms) of MTBE were produced in the United States, and between 1984 and 1994 the amount of MTBE produced has increased by about 26 percent annually (Kirschner, 1995). MTBE is an ether with a structural formula $\mathrm{CH}_{3} \mathrm{OC}\left(\mathrm{CH}_{3}\right)_{3}$. It is a volatile, flammable, colorless liquid at room temperature and has a terpene-like odor. MTBE is miscible in gasoline and is soluble in water, alcohol, and other ethers. It has a relatively high vapor pressure (3.27 to $3.35 \mathrm{X}$
$10^{4} \mathrm{~Pa}$ at $25^{\circ} \mathrm{C}$ ), a high water solubility ( 23.2 to $54.4 \mathrm{~g} / \mathrm{L}$ (grams per liter) at $25^{\circ} \mathrm{C}$ ), and a low octanol/water partition coefficient $\left(\log \mathrm{K}_{\mathrm{ow}} 0.94\right.$ to 1.16), as tabulated by Mackay and others (1993) from numerous investigations. Reported Henry's Law Constant varies from 59 to $305 \mathrm{~Pa} \mathrm{~m} / 30$ (cubic meters per mole) (Mackay and others, 1993) but is generally assumed to be less than $100 \mathrm{~Pa} \mathrm{~m}^{3} / \mathrm{mol}$.

MTBE is on the Hazardous Air Pollutants List with 189 other chemicals to be regulated under the Air Toxics Program of the 1990 Clean Air Act Amendments. Considerable public attention has been focused on MTBE in the atmosphere. Health complaints related to MTBE in the atmosphere were reported in Fairbanks, Alaska, in November 1992 (Begley and Rotman, 1993) when residents reported headaches, dizziness, irritated eyes, burning of the nose and throat, coughing, disorientation, and nausea (Moolenaar and others, 1994) after MTBE had been added to gasoline. Similar health complaints also have been registered across the country including Anchorage, Alaska; Missoula, Montana; Milwaukee, Wisconsin; and cities in New Jersey (Begley and Rotman, 1993; Price, 1995). But the number of complaints in these areas varied. A few epidemiological studies have been conducted in response to public concerns related to the health complaints listed above (Mannino and Etzel, 1993; Moolenaar and others, 1994; White and others, 1995), and a few laboratory studies of healthy adults have been conducted (USEPA, 1994a). Controlled exposure to MTBE in laboratory air did not cause an increase in symptoms or in objective measures of irritation (USEPA, 1994a). Although both of these types of studies have led to a better understanding of human exposures to MTBE, they can neither confirm nor dismiss the existence of acute health effects from exposure to MTBE alone or in gasoline in at least some individuals (USEPA, 1994a).

MTBE is a potentially important ground-water contaminant because of its mobility and persistence (Garrett and Moreau, 1986), and because it is tentatively classified by the USEPA as a possible human carcinogen. In nonoxygenated gasoline, the monocyclic aromatic hydrocarbons, which include benzene, toluene, ethylbenzene, and the three xylenes, $\mathrm{m}-$, o-, and p- (BTEX compounds), are the most 


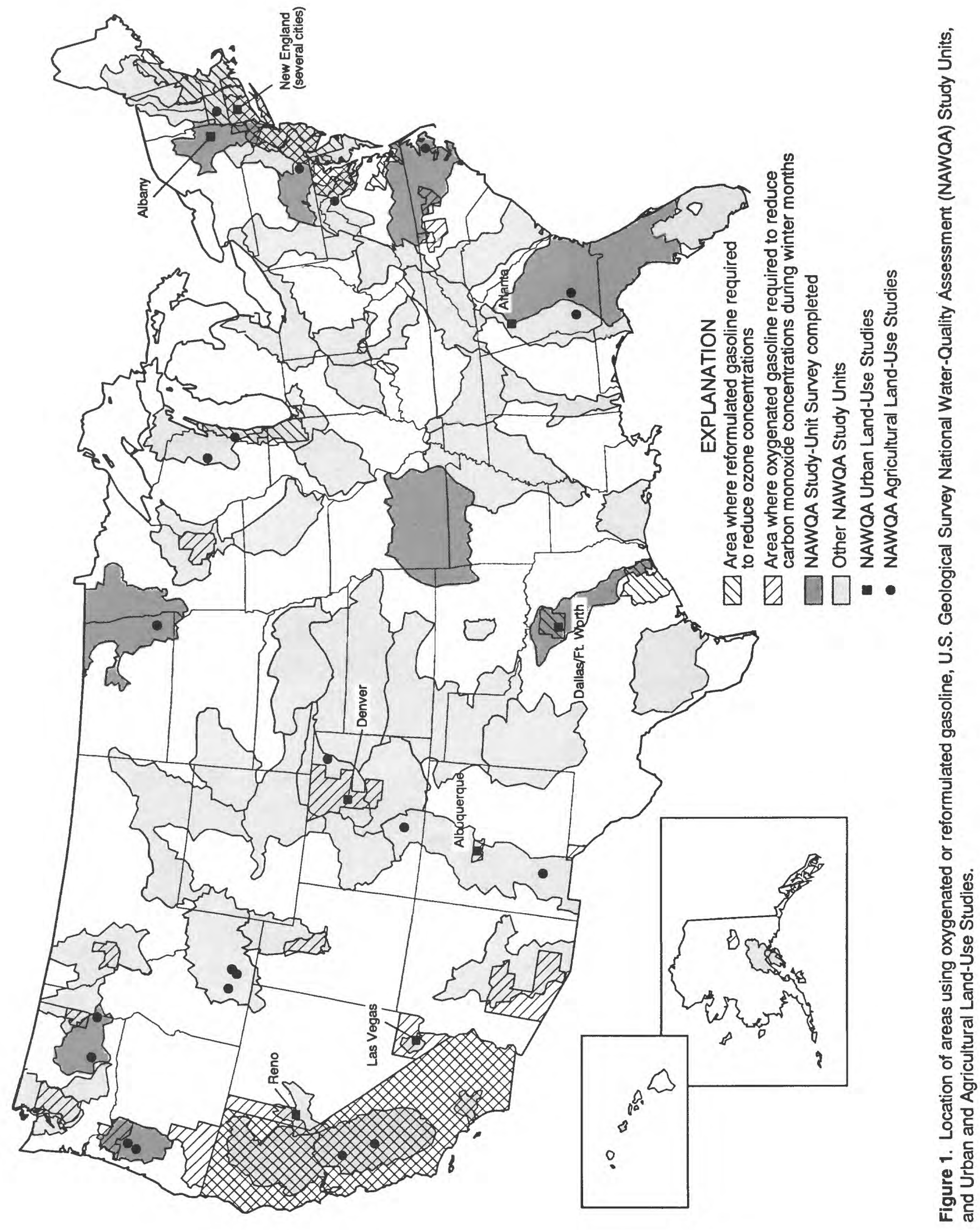


soluble and most mobile components in gasoline. In oxygenated gasoline, MTBE is even more soluble and mobile than any of the BTEX compounds (Garrett and Moreau, 1986; Barker and others, 1990; Luhrs and Pyott, 1992; Odermatt, 1994). In fact, evidence indicates that MTBE moves as rapidly as a conservative tracer (Barker and others, 1990; Hubbard and others, 1994). MTBE persists in ground water under both aerobic and anaerobic conditions (Barker and others, 1990; Suflita and Mormile, 1993; Hubbard and others, 1994; Mormile and others, 1994; Yeh and Novak, 1994) because it resists physical, chemical, and microbial degradation. It is anticipated that the USEPA draft drinking-water lifetime health advisory for MTBE will be assigned a value of 20 or $200 \mu \mathrm{g} / \mathrm{L}$ (micrograms per liter); an advisory of $20 \mu \mathrm{g} / \mathrm{L}$ will be used if the tentative classification as a possible human carcinogen is accepted, otherwise the advisory will be $200 \mu \mathrm{g} / \mathrm{L}$ (USEPA, 1995). The health advisory is the maximum concentration in drinking water that is not expected to cause any adverse effects over a lifetime of exposure, within a specified margin of safety. The USEPA expects to issue the final health advisory in the fall of 1995. MTBE is on the USEPA's Drinking Water Priority List, which means it is a possible candidate for future regulation under the Safe Drinking Water Act. There are no current Federal regulations that require municipalities to test for MTBE in drinking water; consequently, there are few data on the occurrence of MTBE in ground water.

The USEPA has tentatively classified MTBE as a possible human carcinogen on the basis of studies that show MTBE is a carcinogen in animals (BurleighFlayer and others, 1992; Chun and others, 1992; Belpoggi and others, 1995); however, no epidemiological studies have been conducted to determine if MTBE is a human carcinogen. Documents describing the health effects from exposure to MTBE have been written by Environment Canada and Health Welfare Canada (1993), Prah and others (1995), Research Triangle Institute (1994), and the USEPA (1992a, 1994a). Rats and mice exposed to MTBE by inhalation or ingestion showed increased incidence of benign and malignant tumors, and lymphomas and leukemias (Burleigh-Flayer and others, 1992; Chun and others, 1992; Belpoggi and others, 1995). MTBE is absorbed rapidly and extensively from the respiratory and gastrointestinal tracts, and unchanged
MTBE, and to a lesser amount the metabolite tertiary butanol (Savolainen and others, 1985) are the main respiratory excretion products (Research Triangle Institute, 1994). Tertiary butanol has been determined to be a carcinogen in laboratory animals (Cirvello and others, 1995). MTBE also is metabolized to formaldehyde, methanol, formic acid, carbon dioxide, 2methyl-1,2-propanediol, and $\alpha$-hydroxyisobutyric acid (Research Triangle Institute, 1994). MTBE and its metabolites show little tendency to distribute and accumulate in tissues, although MTBE and tertiary butanol may distribute to the brain at concentrations similar to blood concentrations (Research Triangle Institute, 1994). Most MTBE and tertiary-butanol are rapidly excreted (Research Triangle Institute, 1994), but there is evidence showing that a portion of these chemicals are deposited in deeper body stores and are slowly excreted over a longer period of time (Moolenaar and others, 1994; Prah and others, 1995). MTBE is not expected to bioaccumulate in surfacewater aquatic organisms (Research Triangle Institute, 1994).

This report presents preliminary findings on the occurrence and possible sources of MTBE in ground water in selected areas of the United States sampled as part of the U.S. Geological Survey's National Water Quality Assessment (NAWQA) Program. This program is designed to describe current water-quality conditions and trends for 60 of the largest and most important river basins and aquifer systems nationwide (Leahy and Thompson, 1994). Investigations in these 60 areas, referred to as "Study Units," are the principal building blocks of the NAWQA program. Groundwater data from the first 20 Study Units are summarized in this report. The data include analyses from water samples collected from 193 shallow monitoring wells, 12 springs and 5 shallow water supply wells in urban areas; 549 shallow wells in agricultural areas; and 412 wells screened in deeper parts of 9 Study Unit areas representing regionally extensive aquifers. Samples from these wells were analyzed for 60 VOCs, 82 pesticides, up to 17 trace elements, 15 major inorganic compounds, 6 nutrients, and dissolved organic carbon (filtered, $0.45 \mu \mathrm{m}$ (micrometer)). 


\section{STUDY METHODS}

The NAWQA design for ground water focuses on assessing the water-quality conditions of major aquifers in each Study Unit with emphasis on the quality of recently recharged ground water associated with present and recent human activities (Gilliom and others, 1995). The sampling design is based on the need to examine ground-water quality at a range of spatial scales (table 1). "Study-Unit Surveys" are used in conjunction with an analysis of available data to broadly characterize ground-water quality across the Study Unit. Water samples were collected from 412 Study-Unit Survey wells in 9 Study Units representing regionally extensive aquifers (fig. 1) during 1993-94. "Land-Use" Studies are done on an intermediate scale to build an understanding of causal relations and processes. The Land-Use Studies are directed, for the most part, toward the effects of human activities on shallow ambient ground-water quality. There were 210 wells and springs sampled in 8 urban Land-Use Studies and 549 wells sampled in 21 Agricultural Land-Use Studies.

The first step in the design of a Study-Unit Survey is the division of the ground-water resource into aquifer subunits, generally 3 to 5 per Study Unit; priority was given to those aquifer subunits where ground water is used for human consumption. The subunits serve as a first-order subdivision of the Study
Unit into aquifer zones that are expected to be homogeneous in water-quality characteristics compared with the Study Unit as a whole. This subdivision is based mainly on identification of major hydrogeologic settings. For each aquifer subunit, the well-selection process and sampling strategy are designed to achieve a preliminary assessment from a combination of new and existing data. As a general planning guideline, an areal sampling density of at least one well per $100 \mathrm{~km}^{2}$ (square kilometer) is desired, and at least 20 wells are selected in each subunit. Perhaps the most significant factor that affects the utility of Study-Unit Surveys is that locations of existing wells are biased relative to the ground-water resource. Because existing drinkingwater wells generally will not contain large concentrations of contaminants generally associated with pointsource contamination, the Study-Unit Surveys will be biased against large concentrations of contaminants; however, the Study Unit Surveys will probably not be biased relative to smaller concentrations of contaminants generally associated with nonpoint-source contamination. Different type of wells (domestic, public water supply, or irrigation) may be biased in different ways. In general, each Study-Unit Survey uses as few different types of wells as needed to obtain adequate spatial (areally and with depth) distribution of ground-water samples from the aquifer system. Wells are selected for sampling using a grid-based random sampling approach (Scott, 1990).

Table 1. Components and attributes of the National Water-Quality Assessment ground-water sampling design

\begin{tabular}{|c|c|c|c|}
\hline & Study-Unit Survey & $\begin{array}{l}\text { Urban Land-Use } \\
\text { Studies }\end{array}$ & $\begin{array}{l}\text { Agricultural Land-Use } \\
\text { Studies }\end{array}$ \\
\hline General objective & $\begin{array}{l}\text { To supplement existing data in } \\
\text { providing a broad overview of } \\
\text { the quality of "used" ground } \\
\text { water within each Study Unit. }\end{array}$ & \multicolumn{2}{|c|}{$\begin{array}{l}\text { To examine natural and human factors that affect the quality of } \\
\text { shallow ambient ground water that underlie urban and agricultural } \\
\text { areas. }\end{array}$} \\
\hline Spatial scale & $\begin{array}{l}\text { Ground-water resource in study } \\
\text { unit. Spatial density of wells is } \\
\text { generally one well per } 100 \mathrm{~km}^{2} \text {. }\end{array}$ & \multicolumn{2}{|c|}{$\begin{array}{l}\text { Uppermost part of ground-water system in specified land-use } \\
\text { settings. }\end{array}$} \\
\hline Number of areas sampled & $\begin{array}{l}9 \text { Study-Unit areas representing } \\
\text { regionally extensive aquifers. }\end{array}$ & 8 urban areas & 21 agricultural areas \\
\hline \multirow[t]{2}{*}{$\begin{array}{l}\text { Number or kind of wells } \\
\text { sampled }\end{array}$} & 412 total & $\begin{array}{l}5 \text { drinking water wells } \\
193 \text { monitoring wells } \\
12 \text { springs in Atlanta }\end{array}$ & 549 total \\
\hline & & 210 total & \\
\hline
\end{tabular}


Land-Use Studies are designed to assess the concentrations and distribution of water-quality constituents in recently recharged ambient ground water (generally less than 10 years old) associated with the most significant settings of land use and hydrogeologic conditions in each Study Unit. Two to four Land-Use Studies typically are completed in each Study Unit. The priority of potential Land-Use Studies is based on a combination of Study-Unit and National priorities. Factors considered in assigning priorities include importance of the land-use setting to quality of ground water withdrawn and used in the Study Unit, regional significance of the hydrogeologic setting, contamination potential of the targeted land use, and geographic correspondence to subunits concurrently sampled as part of the Study-Unit Survey. Wells selected for a Land-Use Study are randomly distributed throughout the occurrences of the land-use setting of interest within the Study Unit using a grid based random sampling approach (Scott, 1990). Generally, a minimum of 20 wells are sampled in each land-use setting. Some studies used existing wells, others drilled new wells, whereas still others used a combination of new and existing wells. Because of the difficulty in finding suitable wells within Atlanta, Georgia, some springs were sampled, and the results are included with data from the wells in this report. The wells sampled for the Land-Use Studies have a short (ideally less than $3 \mathrm{~m}$ (meters) in length) open interval located near the top of unconfined aquifer. Only wells located in recharge areas underlying or immediately downgradient from the land use of interest are selected. Ideally, observation wells or lowcapacity existing wells are selected to avoid the complexities of determining contributing areas to heavily pumped wells. Many wells are installed by NAWQA to meet these criteria. Well selection and installation procedures are discussed in more detail by Lapham and others (in press).

Because there may be numerous point sources of contamination in an urban area, a randomly located well may be affected directly by nonpoint-, or pointsource contamination, or both. MTBE may be used in gasoline to meet the requirements of the 1990 Clean Air Act Amendments in the urban areas studied (fig. 1). MTBE also may be used in premium gasoline in many of the urban areas studied. To avoid skewing the characterization of water quality toward defined contamination plumes in urban areas, existing wells that were installed to define the downgradient extent of a contamination plume were not considered for sampling. Furthermore, samples were collected from only nine wells that were drilled to define the quality of ambient ground water upgradient of point-source spills. This well-selection process essentially excludes from the study those parts of the aquifer where known point-source plumes are well defined; therefore, depending on the number of defined plumes within the study area, the water-quality data from the Urban Land-Use Studies may be skewed toward nondetectable or lower concentrations of contaminants. For example, if all the point-source contamination in an urban area were defined by observation wells and were sufficiently spread out so that the plumes did not overlap, then none of the wells selected for an Urban Land-Use Study in this area would be affected by, or would characterize, point-source spills. The waterquality data from this hypothetical Urban Land-Use Study would characterize only contaminants from nonpoint sources. In the Denver Urban Land-Use Study, six wells were sampled that were drilled to define the quality of the ambient ground water before it is affected by leakage from a regulated unit as defined by the USEPA (1992b). Samples from all five of these wells had detectable concentrations of MTBE at $0.5,9.6,33,800$, and $23,000 \mu \mathrm{g} / \mathrm{L}$. Two of these wells were upgradient of plumes that were not associated with gasoline sources (Breton Bruce, U.S. Geological Survey, written commun., 1995) although this does not mean that another undefined plume is the source of MTBE in these wells. Samples from these two wells had concentrations of MTBE of 33 and $800 \mu \mathrm{g} / \mathrm{L}$. In the Atlanta Urban Land-Use Study, three wells were located upgradient of plumes, but no MTBE was detected in samples from these wells. None of the other six Urban Land-Use Studies used upgradient wells associated with point-source spills.

Sampling procedures are discussed in Koterba and others (in press) and are briefly summarized here. Submersible pumps were cleaned before a sample was collected. The normal decontamination procedure included an initial flush with nonphosphate detergent, a deionized VOC blank-water rinse, a methanol rinse, and a final deionized water rinse. Samples were collected in an environmental chamber that protected the samples from airborne contamination. Powderless latex gloves were worn whenever a sample was collected. Samples were preserved with hydrochloric 
acid to $\mathrm{pH}$ of 2 and chilled until analyzed by the U.S. Geological Survey's National Water Quality Laboratory in Arvada, Colorado. Study Units with Land-Use Studies collected 73 quality-control samples to assess possible contamination from sample collection and shipment. None of these samples had MTBE concentrations greater than the reporting level of $0.2 \mu \mathrm{g} / \mathrm{L}$.

VOC analyses were performed using purge and trap capillary gas chromatography/mass spectrometry. The method of analysis is discussed in detail by Raese and others (in press) and Rose and Schroeder (1995) and is similar to USEPA Method 524.2, revision 3.0. The precision and accuracy of MTBE analysis in reagent water was demonstrated by 215 laboratory spiked sample analyses performed in 1994-95. The concentrations of MTBE in spiked samples ranged from 0.10 to $5.0 \mu \mathrm{g} / \mathrm{L}$. The mean recovery for each concentration of MTBE analyzed ranged from 83 to 102 percent, and the relative standard deviation ranged from 2.0 to 13.2 percent. MTBE was not detected in any of 277 laboratory blank samples analyzed in 1993-95, and only one laboratory blank sample had a detectable concentration of toluene at $0.2 \mu \mathrm{g} / \mathrm{L}$.

\section{STUDY RESULTS}

\section{Occurrence of MTBE in shallow ground water}

Of the 210 urban wells and springs sampled, 28 percent contained chloroform; 27 percent contained MTBE; 18 percent contained tetrachloroethene; 10 percent contained trichloroethene; 7 percent contained cis-1,2 dichloroethene; 5 percent contained 1,1-dichloroethane; and 5 percent contained benzene. There are many potential sources for these other chemicals; however, 1,1-dichloroethane and benzene are found in gasoline. MTBE generally was not found with BTEX compounds, which commonly are associated with point-source spills of gasoline (fig. 2). Of 210 urban wells and springs sampled 60 wells and 1 spring had concentrations of MTBE or BTEX. Among these 60 wells and 1 spring, 79 percent had MTBE only, 13 percent had MTBE and BTEX, 8 percent had BTEX compounds only. Detectable

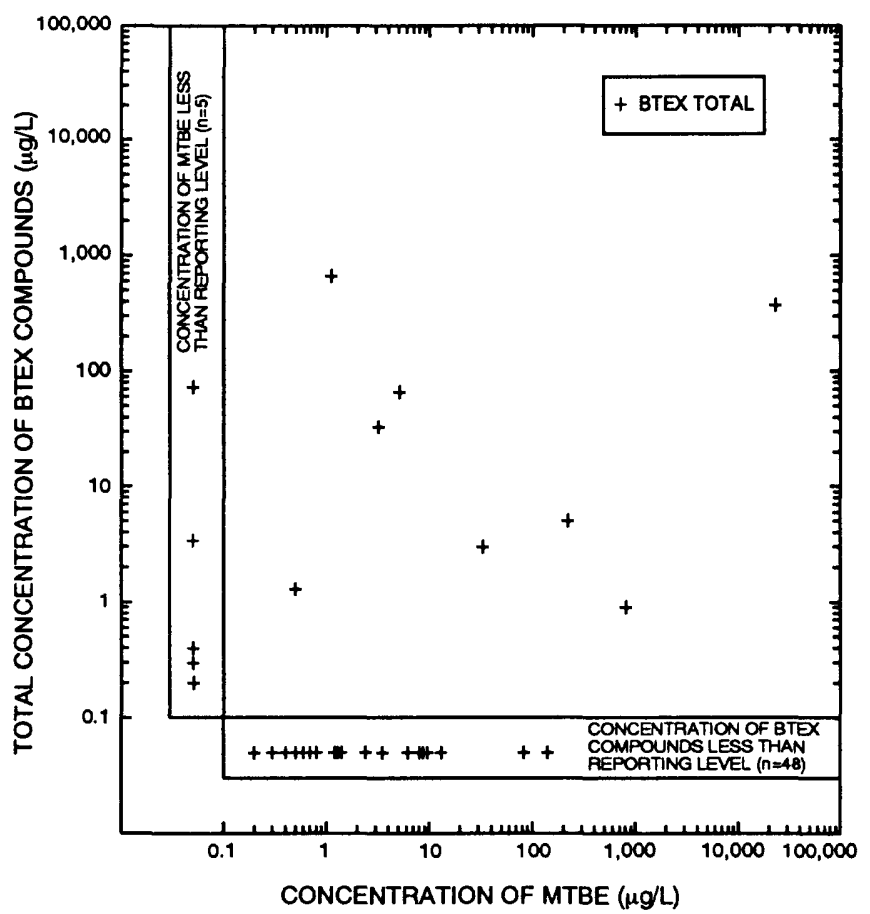

Figure 2. Concentrations of MTBE versus total concentrations of BTEX compounds in shallow ground-water samples from Urban Land-Use Study areas, 1993-94.

concentrations of MTBE were found in 86 percent of the wells sampled in industrial areas (6 of 7 wells), 31 percent of the wells sampled in commercial areas (12 of 39 wells), 23 percent of the wells sampled in residential areas (14 of 61 wells and springs), and 23 percent of the wells sampled in areas of mixed urban land use, parks, and recreation areas (24 of 103 wells and springs).

MTBE was detected more frequently, and in larger concentrations, in shallow ambient ground water in urban areas compared to shallow ground water in agricultural areas. At a reporting level of $0.2 \mu \mathrm{g} / \mathrm{L}$, MTBE was detected in 27 percent of 210 shallow urban wells and springs, and in only 1.3 percent of 549 shallow agricultural wells sampled. MTBE was detected in samples of shallow ground water in all eight urban Land-Use Studies areas but in only 3 of 21 Agricultural Land-Use Studies. In urban areas, MTBE was detected in shallow ground water in Denver, Colorado; New England (specifically urban areas within Connecticut, Massachusetts, and Vermont); Reno, Nevada; Albany, New York; Dallas/Fort Worth, 


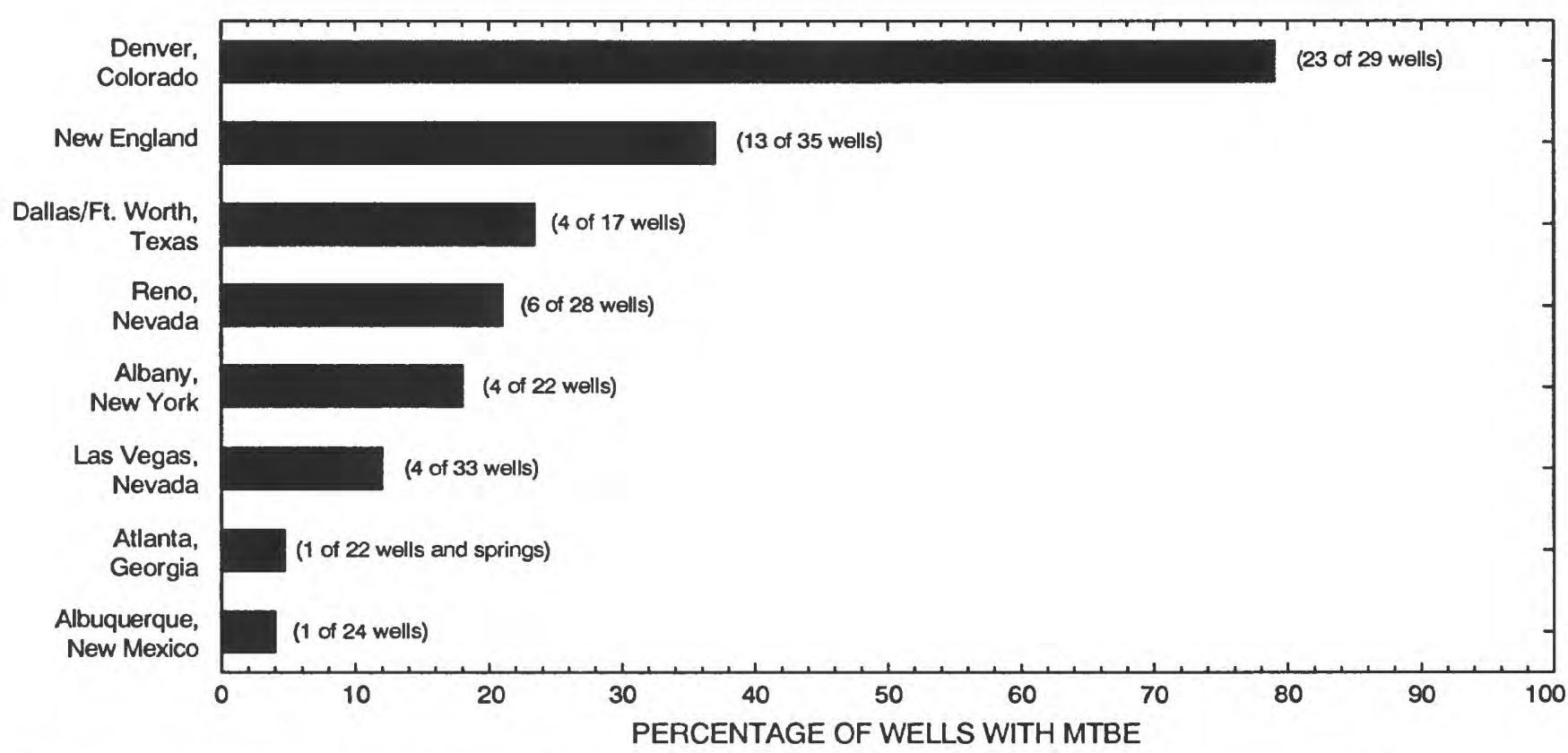

Figure 3. Frequency of detection of MTBE in shallow ground water from Urban Land-Use Study areas, 1993-94.

Texas; Las Vegas, Nevada; Atlanta, Georgia; and Albuquerque, New Mexico (fig. 3). In agricultural areas, MTBE was detected in southern Colorado, New England, and eastern Pennsylvania. The maximum concentration of MTBE detected in shallow ground water in urban areas were over $100 \mu \mathrm{g} / \mathrm{L}$ (fig. 4) whereas the maximum concentration in shallow ground water in agricultural areas was $1.3 \mu \mathrm{g} / \mathrm{L}$. The median value for urban areas lies below the reporting level of $0.2 \mu \mathrm{g} / \mathrm{L}$; however, this median was estimated to be $0.02 \mu \mathrm{g} / \mathrm{L}$ using the maximum-likelihood estimator (Helsel and Hirsch, 1992).

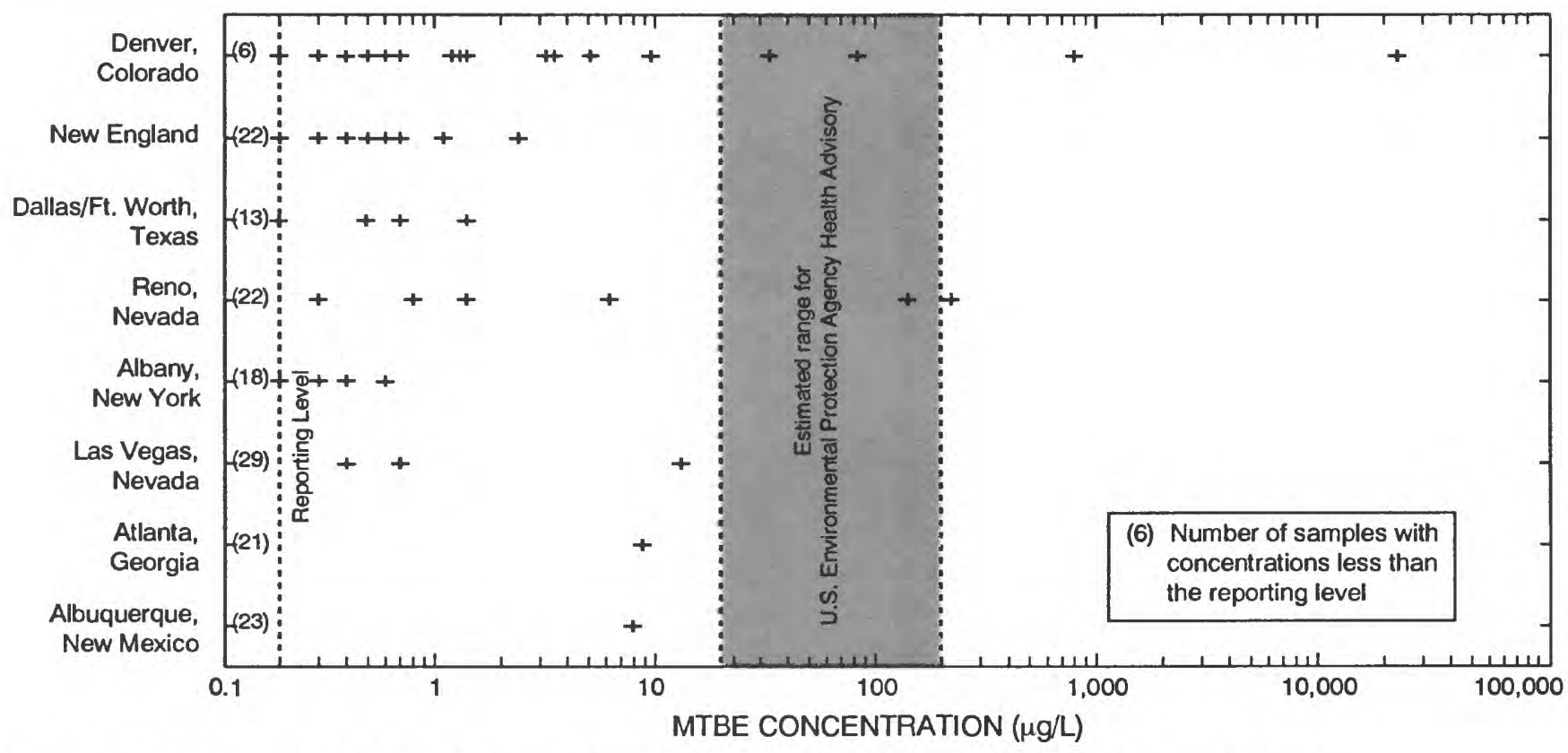

Figure 4. Concentrations of MTBE in shallow ground water from Urban Land-Use Study areas, 1993-94. 
Of the 210 shallow Urban Land-Use wells and springs sampled, 73 percent had concentrations less than the reporting level of $0.2 \mu \mathrm{g} / \mathrm{L}, 24$ percent had concentrations of $\mathrm{MTBE}$ ranging from 0.2 to $20.0 \mu \mathrm{g} / \mathrm{L}$, and 3 percent had concentrations exceeding $20.0 \mu \mathrm{g} / \mathrm{L}$, which is the estimated lower limit of the USEPA (1995) draft drinking-water health advisory level (fig. 4). Five of the 210 shallow urban wells and springs sampled were used as a source of drinking water; however, none of the samples from the 5 drinking-water wells had detectable concentrations of MTBE. In seven of the eight urban areas studied, the sampled ground water was from the uppermost part of an aquifer used for drinking water or possibly was connected to an underlying aquifer that is used as a municipal water supply. In general, public-water supplies draw water from deeper parts of the ground-water system, and the Study-Unit Survey data may provide a better indication of the contaminates that presently exist in drinking-water supplies. None of the samples from the Agricultural Land-Use wells or Study-Unit Survey wells had concentrations of MTBE that exceeded $20.0 \mu \mathrm{g} / \mathrm{L}$.

MTBE was detected most frequently in samples of shallow urban ground water in Denver, Colorado, and New England (fig. 3), but the reason for its frequent detection is not known. In Denver, samples from 79 percent of the shallow urban wells ( 23 of 29 wells) had detectable concentrations of MTBE, and in New England, samples from 37 percent of the wells (13 of 35 wells) had detectable concentrations of MTBE. The frequent detection of MTBE in these two areas may be related to the fact that the aquifer, and the overlying unsaturated zone, consists of very conductive sand and gravel and that the median depth to water was very shallow- $4.3 \mathrm{~m}$ in Denver and $2.8 \mathrm{~m}$ in New England. However, the mean annual precipitation is about three times greater in New England than in Denver (U.S. Geological Survey, 1970), and therefore the ground-water recharge in these two areas may be substantially different.

\section{Relation of MTBE in shallow urban ground water to historical use}

It is difficult to relate the historical use of MTBE with occurrence in ground water because the history of MTBE use in most urban areas is largely unknown. Oxygenated fuels (which include MTBE or other oxygenates such as ethanol) have been used in all gasoline sold during the winter in Denver since 1988, and oxygenated fuels also have been used in the winter in Reno, Las Vegas, and Albuquerque since 1989 (Michael Ball, USEPA, written commun., 1995) where MTBE was detected less frequently in ground water. The amount of MTBE used in oxygenated fuels in these western cities is unknown. Oxygenated fuels were not used in eastern cities until 1992; however, to enhance the octane of gasoline, MTBE has been added to premium gasoline in some areas since 1979 (Garrett and Moreau, 1986). The use of MTBE in premium gasoline was common in New England during the 1980 's and may have led to its frequent detection in shallow urban ground water in 1993-94.

\section{Occurrence of MTBE in deeper ground water}

In deeper ground water, MTBE was detected in 4 of 412 Study-Unit Survey wells (1 percent) in 9 Study Units (fig. 1). Three of these four wells with MTBE were used for domestic or municipal water supply. The maximum concentration of MTBE detected was $1.3 \mu \mathrm{g} / \mathrm{L}$, and no Study-Unit Survey identified more than one well with detectable levels of MTBE. The Study-Unit Survey wells had smaller concentrations and less-frequent occurrence of MTBE than the LandUse wells for three possible reasons: (1) Study-Unit Survey wells were not necessarily located in urban areas where MTBE is used most intensively and is most frequently detected in shallow ground water; (2) Study-Unit Survey wells are deeper, and generally it takes time for a recent contaminant to move into deeper parts of an aquifer; and (3) the concentrations of MTBE become diluted as shallow ground water mixes with deeper, generally cleaner, ground water.

\section{Possible sources of MTBE in ground water}

MTBE in ground water can originate from point and nonpoint sources. Possible point sources of MTBE include leaking gas tanks, pipelines, landfill sites, dumps, spills, industry, underground injection, and refueling facilities. Leaking underground storage tanks are a major source of contamination; about 
22 percent of the 1.2 million petroleum underground storage tanks at more than 500,000 sites in the United States have leaked as of July 1994 (USEPA, 1994b, 1994c). Although MTBE will volatilize from soils, it is also highly mobile in soil and can move into ground water.

The infrequent concurrent detection of MTBE with BTEX compounds suggest that point-source leaks are not the principal source of the MTBE detected in urban ground water, although the lack of association does not completely rule out point-source spills as a potential source. MTBE plumes originating from point-source gasoline spills would generally occupy a larger proportion of the subsurface compared to BTEX compounds, and concentrations of MTBE at the leading edge of the plume would be small but would be expected to increase in time. Therefore, if the small concentrations of MTBE detected in shallow urban ground water originated from gasoline spills, then generally one would expect the concentrations of MTBE and detections of BTEX compounds, to increase with time at these same wells. MTBE plumes will generally occupy a larger portion of the subsurface compared to BTEX compounds for three reasons: (1) MTBE is persistent in aerobic and anaerobic ground water (Barker and others, 1990; Suflita and Mormile, 1993; Hubbard and others, 1994; Mormile and others, 1994; Yeh and Novak, 1994); (2) MTBE can occur in large concentrations in gasoline as previously discussed; and (3) MTBE does not sorb to aquifer material and is more mobile in ground water than other BTEX compounds based on field data and physical and chemical properties (solubility, vapor pressure, $\mathrm{K}_{\mathrm{ow}}$ and $\mathrm{K}_{\mathrm{oc}}$ ) (Garrett and Moreau, 1986; Barker and others, 1990; Luhrs and Pyott, 1992; Odermatt, 1994). In fact, evidence indicates that MTBE moves as rapidly as a conservative tracer (Barker and others, 1990; Hubbard and others, 1994) and that MTBE plumes are likely to undergo only dispersive attenuation.

Possible nonpoint sources of MTBE include atmospheric deposition and stormwater runoff. Once in the atmosphere, MTBE can partition into precipitation and be transported in stormwater runoff into streams or into shallow ground water with recharge from stormwater runoff or infiltration of precipitation. MTBE is released to the atmosphere from a variety of sources including industrial discharges, and mobile sources such as automobiles, and during refueling of automobiles. With the possible exception of industry, the amount of MTBE released to urban atmosphere from various sources is not well documented; therefore, the principal source of atmospheric MTBE can not be easily identified. Refueling at service stations is a source of MTBE to the atmosphere, but there have been only a few studies that measured concentrations in the atmosphere (Johnson and others, 1994; Anderson and others, 1995). In 1992, the release of MTBE from industry in the United States accounted for only 0.03 percent of the MTBE that was produced. According to USEPA's Toxic Release Inventory (1994d), about 94 percent of the MTBE released from industry was released to the atmosphere, 3.5 percent was discharged to surface water, and 2.5 percent was injected into wells. Recent evidence indicates that evaporative emissions from vehicles are far higher than had been thought (Stump and others, 1990; Calvert and others, 1993). Exhaust emissions of MTBE ranged from 0.9 to $81 \mathrm{mg} / \mathrm{km}$ (milligrams per kilometer) for various vehicles using gasoline with 11-16 percent MTBE by volume (Stump and others, 1990; Hoekman, 1992; Calvert and others, 1993). However, most mobile-source emissions are caused by a small percentage of the vehicles (Slinn and others, 1978); therefore, large errors may result when extrapolating emissions data for a few vehicles to the total vehicle population.

The transfer of MTBE from atmospheric gases to rainwater is dependent on the temperature and concentrations of MTBE in the air. Very little MTBE would be expected to partition to organic carbon or water on dust and other particulates in the atmosphere because of MTBE's high vapor pressure and the small amount of water that would be expected on particulates. Thus, the concentration of MTBE in precipitation can be predicted using a modified form of Henry's Law, assuming MTBE is in the gaseous phase and the concentrations in the atmosphere and in precipitation are in equilibrium. This equilibrium condition is supported by Slinn and others (1978) and Ligocki and others (1985). Slinn and others (1978) showed that a gas will reach equilibrium with falling raindrops within a few tens of meters of fall distance if the gas does not participate in chemical reactions within the droplet. 
The concentration of a chemical in water can be calculated using the following equation presented by Schwarzenbach and others (1993):

where

$$
C_{w}=\frac{C_{a} R T}{K_{H}}
$$

$$
\begin{aligned}
C_{w}= & \begin{array}{l}
\text { concentration of the chemical in water, in } \\
\text { moles per liter; }
\end{array} \\
C_{a}= & \begin{array}{l}
\text { concentration of the chemical in the } \\
\text { atmosphere, in moles per liter; }
\end{array} \\
R= & \begin{array}{l}
\text { gas constant of } 8.21 \times 10^{-2} \text { atm } \mathrm{L} /\left(\mathrm{mol}^{\circ} \mathrm{K}\right) \\
\text { (atmosphere-liters per mole degrees }
\end{array} \\
& \text { kelvin) } \mathrm{K} ; \\
T= & \text { temperature, in degrees kelvin; and } \\
K_{H}= & \begin{array}{l}
\text { Henry's Law Constant, in atmosphere- } \\
\text { liters per mole. }
\end{array}
\end{aligned}
$$

Robbins and others (1993) showed that the temperature dependence of $K_{H}$ for MTBE can be estimated using the following equation for temperatures ranging from 298.18 to $323.18^{\circ} \mathrm{K}$, or 25 to $50^{\circ} \mathrm{C}$ :

$$
K_{H}=1000 \exp \left(18.4-\frac{7666}{T}\right)
$$

where

$T=$ temperature, in degrees kelvin.

Equation 2 shows that Henry's Law constant increases by a factor of about 2 for every 10-degree increase in temperature. Thus, assuming a constant concentration of MTBE in the atmosphere, concentrations of MTBE in precipitation would be significantly greater during winter months than in warmer summer months. Figure 5 shows this relationship assuming the relation established by Robins and others (1993) holds for temperatures below $25^{\circ} \mathrm{C}$. This figure shows that assuming a concentration of $2 \mathrm{ppb}$ (parts per billion) MTBE in the atmosphere, the concentration of MTBE in precipitation would increase almost tenfold, from about 0.4 to $3 \mu \mathrm{g} / \mathrm{L}$, if the temperature decreases from 20 to $0^{\circ} \mathrm{C}$ (fig. 5). Therefore, the lower the temperature, the greater the concentration of MTBE in precipitation given a constant concentration in the atmosphere. This relation is important because MTBE is used in the winter to control the concentrations of carbon monoxide in the atmosphere.

Relatively few data are available on the concentrations of MTBE in the urban atmosphere. However,

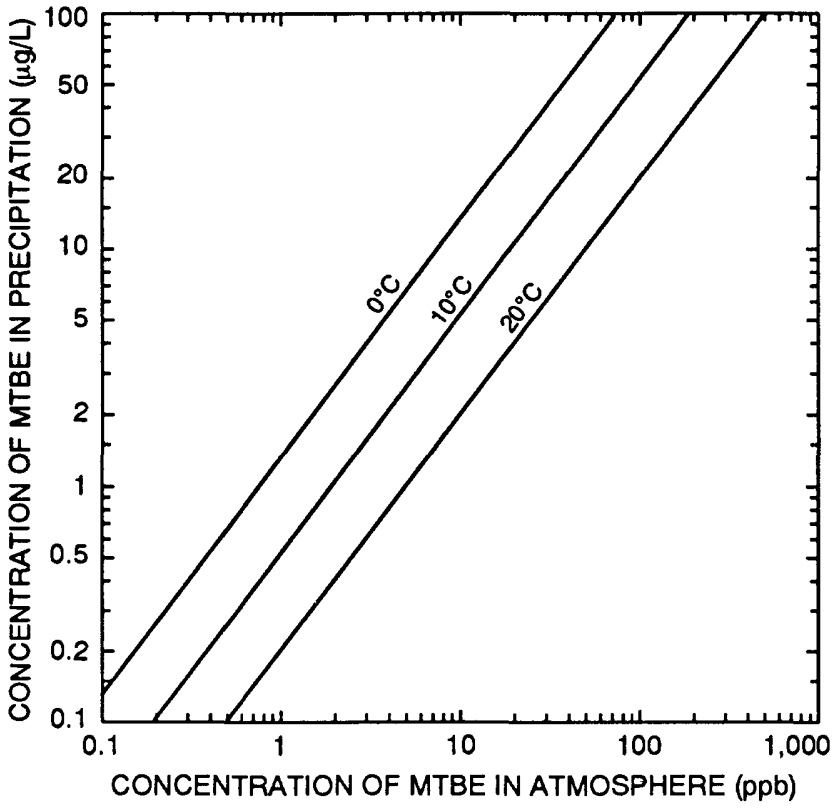

Figure 5. Concentrations of MTBE in atmosphere and precipitation at various temperatures.

reported concentrations of MTBE in the atmosphere, including the air along roadsides, varied from less than 0.025 to $8.4 \mathrm{ppb}$ (LaGrone, 1991; Kelly and others, 1993; Allen and Grande, 1995; Anderson and others, 1995). Concentrations were larger near pointsource release areas. For example, the median concentrations of MTBE in the air at the perimeter of three refueling stations varied from 3 to $14 \mathrm{ppb}$ (Johnson and others, 1994), and the largest concentration was $140 \mathrm{ppb}$ (Johnson and others, 1994). The amount of MTBE released, wind direction, temperature, and distance from the source all would affect the concentrations of MTBE in the atmosphere at any one location. Because of dispersion, mixing, and MTBE's relatively short half-life in the atmosphere of 1 to 11 days (Howard and others, 1991) the concentrations of MTBE in the atmosphere and in precipitation would be expected to decrease with distance from the source.

Stormwater runoff may be another important nonpoint source of MTBE to ground water. The U.S. Geological Survey has collected stormwater-runoff samples in Dallas/Fort Worth, Texas; Denver/Lakewood, Colorado; Albuquerque, New Mexico; and Colorado Springs, Colorado, and elsewhere, to help municipalities meet the National Pollutant Discharge Elimination System (NPDES) monitoring requirements set by the USEPA. The 
above noted four cities currently are using fuel oxygenates in gasoline to meet requirements of the 1990 Clean Air Act Amendments. Stormwater samples were collected between February 1992 and May 1993, and during the summer, when MTBE is not used ubiquitously in gasoline. MTBE was detected in 14 percent of the 279 stormwater samples collected. Concentrations of MTBE ranged from the reporting level of 0.2 to $8.3 \mu \mathrm{g} / \mathrm{L}$. When detected, the median concentration of MTBE in stormwater was $1.4 \mu \mathrm{g} / \mathrm{L}$. Colorado Springs had the greatest number of detections of MTBE at 36 percent (15 of 42 samples) and Albuquerque had the fewest with 3 percent ( 1 of 30 samples). In Colorado Springs, MTBE was detected in samples collected during the winter only when MTBE was used as a fuel oxygenate in gasoline (von Guerard and Weiss, 1995).

\section{CONCLUSIONS AND DISCUSSION}

Out of the 60 VOCs for which analyses were made, MTBE was second most commonly detected in samples of shallow ambient ground water from urban areas throughout the United States. MTBE was detected most frequently in shallow ground water in urban areas when compared to shallow ground water in agricultural areas, or to deeper ground water from major aquifers. At a reporting level of $0.2 \mu \mathrm{g} / \mathrm{L}$, MTBE was detected in samples from 27 percent of the shallow Urban Land-Use wells and springs, from only 1.3 percent of the shallow Agricultural Land-Use wells, and from 1 percent of the deeper wells in major aquifers. In Denver, Colorado, samples from 79 percent of the shallow Urban Land-Use wells had detectable concentrations of MTBE, and in New England, samples from 37 percent of the Urban LandUse wells had detectable concentrations. None of the five drinking-water wells sampled in urban areas had detectable concentrations of MTBE. The infrequent concurrent detection of MTBE with BTEX compounds suggests that nonpoint sources may be the principal source of the MTBE detected in ambient urban ground water, although the lack of association does not completely rule out point-source spills as a potential source.

Based on the USEPA's current understanding of MTBE's carcinogenicity, the concentrations in ground water reported in this study in most cases do not represent a risk to human health; samples from only 3 percent of the shallow wells and springs in urban areas had concentrations of MTBE that exceeded $20 \mu \mathrm{g} / \mathrm{L}$, which is the estimated lower limit of the USEPA's draft drinking-water health advisory. Currently, MTBE is not a target analyte of monitoring programs of public water supplies and drinking water; however, MTBE can be analyzed by purge and trap, capillary column gas chromatography/mass spectrometry (Raese and others, in press), which is extensively used for VOC analysis by public-water utilities. Given the preliminary information discussed in this report, it may be advisable for urban water utilities to consider adding MTBE to their existing VOC analytical schedule.

How MTBE enters shallow urban ground water is not clear, and existing environmental monitoring programs may not be adequately designed to answer this question. Federal, State and local government agencies have made substantial investments to protect the quality of the environment, and the effectiveness of these efforts has been evaluated by assessing the resource that was focused for protection (for example, air, surface water, and ground water). The integration of monitoring programs would help to insure that efforts to protect or improve one component of the environment do not adversely affect another. Integrated environmental monitoring in a few major cities would provide an improved understanding of the source, transport, and fate of MTBE in ground water in urban areas.

Defining the source of MTBE in shallow ground water is essential to prevent further contamination, and to protect other vulnerable aquifers in the United States from contamination by MTBE or similar compounds. Questions related to the source of MTBE include: (1) Is the frequency of detection of MTBE in shallow ground water more related to its use or to aquifer vulnerability? (2) Is the source of MTBE in shallow ambient urban ground water primarily from nonpoint sources of contamination, such as precipitation and urban runoff? There may be areas of the country where the use of MTBE will not result in its infiltration to shallow or deeper ground water. However, before this can be determined, seasonal information is needed on how much MTBE is being used in major metropolitan areas. This information can be related to the frequency of detection of MTBE 
and to aquifer vulnerability. To define nonpoint sources of MTBE contamination, information is needed on the release of MTBE to the atmosphere from various activities. MTBE can be released to the atmosphere from a variety of sources including industrial stack and fugitive emissions, refueling at service stations, and mobile sources, such as automobiles. With the possible exception of industrial emissions, the amount of MTBE released to the urban atmosphere from these other sources is not well documented. Once MTBE is in the atmosphere, some can be returned with precipitation, but more research is needed to determine the concentrations of MTBE in precipitation and in surface runoff on a seasonal basis.

A better understanding of the transport of MTBE from land surface to shallow ground water, and from shallow to deeper aquifers would be used to protect public water supplies and in developing wellhead protection plans for public water supplies. Questions related to the transport of MTBE include: (1) Can MTBE in precipitation or stormwater runoff recharge the shallow ground water; if so, under what conditions and in what concentrations? (2) How quickly, and at what concentrations, can MTBE be transported from shallow to deeper ground water? (3) What is the maximum extent of a MTBE plume originating from a point source relative to the BTEX compounds? Depth to water, recharge rates, permeability of the unsaturated zone, and other hydrogeologic characteristics are likely to affect the transport of MTBE through the unsaturated zone. Because MTBE is mobile and persistent in ground water, it is reasonable to expect that it will move from shallow to deep ground water with time, but it is not known how quickly and at what concentrations. Knowledge on the maximum extent of a MTBE plume relative to BTEX compounds originating from a single gasoline contamination source will help determine if point-source contamination is responsible for the widespread detection of small concentrations of MTBE in the absence of BTEX compounds.

Additional study and data on the fate of MTBE are needed to determine if MTBE, or its degradation products, will accumulate in ground water over time. The accumulation of MTBE in ground water may not necessarily result in an increase in concentrations with time, but its detection would become more frequent. The degradation of some organic chemicals in aquifers can be very slow, with a half life of decades or longer, to breakdown to carbon dioxide and water.
The degradation products of some organic chemicals can be toxic. Questions related to the fate of MTBE include: (1) What is the long-term fate of MTBE, and its degradation products, in ground water? (2) What is the half life of MTBE in ground water under aerobic and anaerobic conditions in various aquifers? There also may be degradation products of MTBE in the air, such as tert-butyl formate (Japar and others, 1991), which enter shallow ground water with recharge water. Investigation of these degradation products is necessary to a full understanding of the fate of MTBE.

In order to determine if MTBE concentrations are likely to rise above current levels and potentially rise to levels that pose a health threat, it is necessary to understand three things about the compound: (1) the pathways by which it enters the ground water, (2) the processes by which it is transported in ground water, and (3) the rates at which it degrades. Only when all three of these issues are reasonably well understood can meaningful projections be made of the potential for MTBE reaching dangerous levels over long periods of use. The U.S. Geological Survey is beginning to conduct research on aspects of all of these processes and is in close communication with other scientists studying these questions. In addition, the NAWQA program will continue to monitor some wells in all Study Units, providing a continuing empirical check on the changes in levels of MTBE in ground water. The U.S. Geological Survey will continue to report to the public, regulatory agencies, industry, and the scientific community on the results of its research and monitoring on this emerging waterquality issue.

\section{REFERENCES CITED}

Ainsworth, S., 1992, Oxygenates seen as hot market by industry: Chemical Engineering News, v. 70, p. 26-30.

Allen, M. and Grande, D., 1995, Reformulated gasoline air monitoring study: Madison, Wisconsin Department of Natural Resources, AM-175-95, 24 p.

Anderson, H.A., Hanrahan, Lawrence, Goldring, Jay, and Delaney, Bryan, 1995, An investigation of health concerns attributed to reformulated gasoline use in southeastern Wisconsin: Madison, Wisconsin Department of Health and Social Services, $99 \mathrm{p}$. 
Barker, J.F., Hubbard, C.E., and Lemon, L.A., 1990, The influence of methanol and MTBE on the fate and persistence of monoaromatic hydrocarbons in ground water, in Proceedings of Petroleum Hydrocarbons and Organic Chemicals in Ground Water Prevention, Detection, and Restoration, October 31-Nov. 2, 1990: Houston, Texas, American Petroleum Institute and Association of Ground Water Scientists and Engineers, p. 113-127.

Begley, Ronald, and Rotman, David, 1993, Health complaints fuel federal concern over MTBE: Chemical Week, v. 152, no. 10, p. 7.

Belpoggi, F., Soffritte, M., and Maltoni, C., 1995, Methyltertiary-butyl ether (MTBE)-a gasoline additivecauses testicular and haematopoeitic cancers in rats: Toxicology and Industrial Health, v. 11, no. 2, p. 119150.

Burleigh-Flayer, H.D., Chun, J.S., and Kintish, W.J., 1992, Methyl tertiary butyl ether--vapor inhalation oncologenicity study in CD-1 mice: Export, Pennsylvania, Union Carbide, Bushy Run Research Center, BRRC report 91N0013B.

Calvert, J.G., Heywood, J.B., Sawyer, R.F., and Seinfeld, J.H., 1993, Achieving acceptable air quality: some reflections on controlling vehicle emissions: Science, v. 261 , p. $37-45$.

Chun, J.S., Burleigh-Flayer, H.D., and Kintish, W.J., 1992, Methyl tertiary butyl ether--Vapor inhalation oncologenicity study in Fisher-344 rats: Export, Pennsylvania, Union Carbide, Bushy Run Research Center, BRRC report 91N0013B.

Cirvello, J.D., Radovsky, Ann, Heath, J.E., Farnell, D.R., and Lindamood, Charles, 1995, Toxicity and carcinogenicity of t-butyl alcohol in rats and mice following chronic exposure in drinking water: Toxicology and Industrial Health, v. 11, no. 2, p. 151-166.

Environment Canada and Health and Welfare Canada, 1993, Canadian Environmental Protection Act Priority Substances List supporting document methyl tertiarybutyl ether: Hull, Quebec, 18 p.

Garrett, Peter, Moreau, Marcel, and Lowry, J.D., 1986, MTBE as a groundwater contaminant, in Proceedings of Petroleum Hydrocarbons and Organic Chemicals in Ground Water Prevention, Detection, and Restoration: Houston, Texas, National Water Well Association and American Petroleum Institute, p. 227-238.
Gilliom, R.J., Alley, W.M., and Gurtz, M.E., 1995, Design of the National Water Quality Assessment ProgramOccurrence and distribution of water-quality conditions: U.S. Geological Survey, Circular 1112, $33 \mathrm{p}$.

Helsel, D.R., Hirsch, R.M., 1992, Statistical Methods in Water Resources: Elsevier, New York, 525 p.

Hoekman, S.K., 1992, Speciated measurements and calculated reactivities of vehicle exhaust emissions from conventional and reformulated gasolines: Environmental Science and Technology, v. 26, no. 6, p. 1206-1216.

Howard, P.H., Boethling, R.S., Jarvis, W.F., Meylan, W.M., and Michalenko, E. M., 1991, Handbook of environmental degradation rates: Chelsea, Michigan. Lewis Publishers, Inc., p. 653-654.

Hubbard, C.E., Barker, J.F., O'Hannesin, S.F., Vandegriendt, M., and Gillham, R.W., 1994, Transport and fate of dissolved methanol, methyl-tertiary butylether, and monoaromatic hydrocarbons in a shallow sand aquifer: Washington, D.C., American Petroleum Institute.

Japar, S.M., Wallington, T.J., Rudy, S.J., and Chang, T.Y., 1991, Ozone forming potential of a series of oxygenated organic compounds: Environmental Science and Technology, v. 25, no. 3, p. 415-420.

Johnson, Ted, McCoy, Michael, and Wisbith, Tony, 1994, A study to characterize air concentrations of methyl tertiary butyl ether (MTBE) at service stations in the Northeast: American Petroleum Institute, Publication \#4619, Washington, DC., 75 p.

Kelly, T.J., and Callahan, P.J., Piell, J., and Evans, G.F., 1993, Method development and field measurements for polar volatile organic compounds in ambient air: Environmental Science and Technology, v. 27, no. 6, p. 1146-1153.

Kirschner, E.M., 1995, Production of top 50 chemicals increased substantially in 1994: Chemical \& Engineering News, April 10, 1995, p. 16-22.

Koterba, M.T., Wilde, F.D., and Lapham, W.W., in press, Ground water data-collection protocols and procedures for the National Water-Quality Assessment Program Collection and documentation of water quality samples and data: U.S. Geological Survey Open-File Report 95-399. 
LaGrone, F.S., 1991, Potential community exposure to toxic chemicals: Environmental Science and Technology, v. 25, no. 3, p. 366-368.

Lapham, W.W., Wilde, Franceska D., and Koterba, M.T., in press, Ground-water data-collection protocols and procedures for the National Water Quality Assessment Program--Well selection, installation, and documentation and collection of wells and related data: U.S. Geological Survey Open-File Report 95-398.

Leahy, P.P., and Thompson, T.H., 1994, U.S. Geological Survey National Water Quality Assessment Program: U.S. Geological Survey Open-File Report 94-70, 4 p.

Ligocki, M.P., Leuenberger, C., and Pankow, J.F., 1985, Trace organic compounds in rain II. Gas scavenging of neutral organic compounds: Atmospheric Environment, v. 19, no. 10, p. 1609-1617.

Luhrs, R.C., and Pyott, C.J., 1992, Trilinear plots a powerful new application for mapping gasoline contamination, in Proceedings of Petroleum Hydrocarbons and Organic Chemicals in Ground Water-Prevention, Detection and Restoration, Eastern Regional Water Issues, November 4-6, 1992: Houston, Texas, American Petroleum Institute and Association of Ground Water Scientists and Engineers, p. 85-100.

Mackay, Donald, Shiu, W.Y., and Ma, K.C., 1993, Illustrated handbook of physical-chemical properties and environmental fate for organic chemicals-Volume III, Volatile organic chemicals: Ann Arbor, Michigan, Lewis Publishers, $916 \mathrm{p}$.

Mannino, D.M., and Etzel, R.A., 1993, An investigation of exposure to MTBE and gasoline among motorists and exposed workers in Albany, New York: Atlanta, Georgia, Center for Disease Control and Prevention, National Center for Environmental Health. Division of Environmental Health Hazards and Health Effects, $23 \mathrm{p}$.

Moolenaar, R.L., Hefflin, B.J., Ashley, D.L., Middaugh, J.P., and Etzel, R. A., 1994, Methyl tertiary butyl ether in human blood after exposure to oxygenated fuel in Fairbanks, Alaska: Archives of Environmental Health, v. 49 , no. 5 , p. $402-409$.

Mormile, M.R., Liu, Shi, and Suflita, J.M., 1994, Anaerobic biodegradation of gasoline oxygenates: extrapolation of information to multiple sites and redox conditions: Environmental Science and Technology, v. 28, p. 1727-1732.
Odermatt, J.R., 1994, Natural chromatographic separation of benzene, toluene, ethylbenzene, and xylenes (BTEX compounds) in a gasoline contaminated ground water aquifer: Organic Chemistry, v. 21, no. 10/11, p. 1141-1150.

Prah, J.D., Ashley, D., House, D., Cohen, K.L., Gerrity, T., 1995, Sensory, symptomatic, inflammatory, and ocular responses to and the metabolism of methyl tertiary butyl ether in a controlled human exposure experiment: Inhalation Toxicology, v. 6, p. 521-538.

Price, Joyce, 1995, Gas is greener, but smog safer: Insight On The News, v. 11, no. 16, p. 27.

Raese, J.W., Sandstrom, M.W., and Rose, D.L., in press, U.S. Geological Survey laboratory method for tertbutyl ether and other fuel oxygenates: U.S. Geological Survey Fact Sheet FS-219-95.

Research Triangle Institute, 1994, Draft toxicological profile for methyl tert-butyl ether: Atlanta, Georgia, U.S. Department of Health and Human Services, Public Health Service Agency for Toxic Substances and Disease Registry, $185 \mathrm{p}$.

Robbins, G.A., Wang, Suya, and Stuart, J.D., 1993, Using the static headspace method to determine Henry's, law constants: Analytical Chemistry, v. 65 , no. 21, p. 3113-3118.

Rose, D.L., and Schroeder, M.P., 1995, Method of analysis by the U.S. Geological Survey National WaterQuality Laboratory--Determination of volatile organic compounds in water by purge and trap capillary gas chromatography/mass spectrometry: U.S. Geological Survey Open-File Report 94-708, 26 p.

Savolainen, H.P., Pfaffli, Pirrko, and Elovaara, Eivov, 1985, Biochemical effects of methyl tertiary butyl ether in extended vapor exposure of rats: Archives of Toxicology, v. 57, no. 4, p. 285-288.

Schwarzenbach, R.P., Gschwend, P.M., and Imboden, D.M., 1993, Environmental organic chemistry: New York, John Wiley and Sons, Inc., $681 \mathrm{p}$.

Scott, J.C., 1990, Computerized stratified random siteselection approaches for design of ground waterquality sampling network: U.S. Geological Survey Water-Resources Investigations Report 90-4104, $109 \mathrm{p}$. 
Shelly, S., and Fouhy, K., 1994, The drive for cleaner burning fuel: Chemical Engineering, January, p. 6163.

Slinn, W.G.N., Hasse, L., Hicks, B.B., Hogan, A.W., Lal, D., Liss, P.L., Munnich, K.O., Sehmel, G.A., and Vittori, O., 1978, Some aspects of the transfer of atmospheric trace constituents past the air-sea interface: Atmospheric Environment, v. 12, p. 2055-2087.

Stump, F.D., Knapp, K.T., and Ray, W.D., 1990, Seasonal impact of blending oxygenated organics with gasoline on motor vehicle tailpipe and evaporative emissions: Journal of Air \& Waste Management Association, v. 40, no. 6 , p. $872-880$.

Suflita, J.M., and Mormile, M.R., 1993, Anaerobic biodegradation of known and potential gasoline oxygenates in the terrestrial subsurface: Environmental Science and Technology, v. 27, p. 976-978.

U.S. Environmental Protection Agency, 1992a, Methyl-tbutyl ether-drinking water health advisory: Washington, D.C., Office of Science and Technology, Health and Ecological Criteria Division, 31 p.

1992b, RCRA groundwater monitoring draft technical guidance: Office of Solid Waste, Washington, DC.

1994a, Health risk perspective on fuel oxygenates: EPA 600/R-94/217, Office of Research and Development, December, $11 \mathrm{p}$.

1994b, UST program facts- overview of the UST program: EPA 510-F-94-008, Solid Waste and Emergency Response, August, 2 p. 1994c, UST program facts- cleaning up releases: EPA 510-F-94-006, Solid Waste and Emergency Response, August, 2 p.

1994d, Toxics release inventory public data release: Office of Pollution Prevention and Toxics, Washington, DC, EPA 745-R-94-001, 288 p.

1995, Drinking water regulations and health advisories: Office of Water, Washington, DC, $16 \mathrm{p}$.

U.S. Geological Survey, 1970, The national atlas of the United States of America: Department of the Interior, $417 \mathrm{p}$.

von Guerard, Paul, and Weiss, W.B., 1995, Water quality of storm runoff and comparison of procedures for estimating storm-runoff loads, volume, event-mean concentrations, and the mean load for a storm for selected properties and constituents for Colorado Springs, Southeastern Colorado: U.S. Geological Survey Water-Resources Investigations Report 94$4194,68 \mathrm{p}$.

White, M.C., Johnson, C.A., Ashley, D.L., Buchta, T.M., and Pelletier, D.J., 1995, Exposure to methyl tertiary butyl ether from oxygenated gasoline in Stamford, Connecticut: Archives of Environmental Health, v. 50, no. 3, p. 183-189.

Yeh, C.K., and Novak, J.T., 1994, Anaerobic biodegradation of gasoline oxygenates in soils: Water Environment Research, v. 66, no. 5, p. 744-752. 